\title{
Comparative studies of praseodymium(III) selective sensors based on newly synthesized Schiff's bases
}

\author{
Vinod K. Gupta*,1, Rajendra N. Goyal, Manoj K. Pal, Ram A. Sharma \\ Department of Chemistry, Indian Institute of Technology Roorkee, Roorkee 247 667, India
}

\section{A R T I C L E I N F O}

\section{Article history:}

Received 21 July 2009

Received in revised form 3 September 2009

Accepted 4 September 2009

Available online 9 September 2009

\section{Keywords:}

Ion selective electrode

Praseodymium ion

Schiff base

Polyvinyl chloride membranes

\begin{abstract}
A B S T R A C T
Praseodymium ion selective polyvinyl chloride (PVC) membrane sensors, based on two new

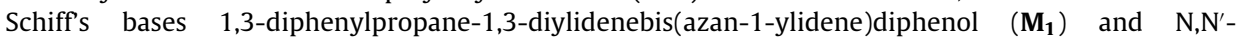
bis(pyridoxylideneiminato) ethylene $\left(\mathbf{M}_{2}\right)$ have been developed and studied. The sensor having membrane composition of PVC: o-NPOE: ionophore $\left(\mathbf{M}_{\mathbf{1}}\right)$ : NaTPB $(w / w ; m g)$ of 150: 300: 8: 5 showed best performances in comparison to $\mathbf{M}_{\mathbf{2}}$ based membranes. The sensor based on $\left(\mathbf{M}_{1}\right)$ exhibits the working concentration range $1.0 \times 10^{-8}$ to $1.0 \times 10^{-2} \mathrm{M}$ with a detection limit of $5.0 \times 10^{-9} \mathrm{M}$ and a Nernstian slope $20.0 \pm 0.3 \mathrm{mV}$ decade $^{-1}$ of activity. It exhibited a quick response time as $<8 \mathrm{~s}$ and its potential responses were $\mathrm{pH}$ independent across the range of 3.5-8.5.The influence of the membrane composition and possible interfering ions have also been investigated on the response properties of the electrode. The sensor has been found to work satisfactorily in partially non-aqueous media up to $15 \%(v / v)$ content of methanol, ethanol or acetonitrile and could be used for a period of 3 months. The selectivity coefficients determined by using fixed interference method (FIM) indicate high selectivity for praseodymium(III) ions over wide variety of other cations. To asses its analytical applicability the prepared sensor was successfully applied for determination of praseodymium(III) in spiked water samples.
\end{abstract}

(C) 2009 Elsevier B.V. All rights reserved.

\section{Introduction}

Praseodymium a soft silvery metal having anticorrosion property, is used in the aircrafts engines as an alloying agent with magnesium to impart high strength metal. It is also used as a coloring agent in glasses and enamels to produces an intense clean yellow color [1]. Praseodymium-germanium (silicon) alloys are used as superconductor [2]. Now a day, number of methods has been reported for the determination of praseodymium in real sample analysis, such as, absorption spectra of $4 \mathrm{~d}$ electron transitions, derivative spectroscopy, and some other spectroscopic method. However, these techniques require expertise and infrastructure backup; hence, a simple and low cost method needs to be developed for the analysis of praseodymium in large number of environmental samples. A literature survey revels that only two sensors [3,4] have been reported to determine praseodymium(III) concentration in real samples, but they two have limitations of narrow working concentration range and interference to various metal cations. Thus, a good sensor for praseodymium still needs to be developed.

\footnotetext{
* Corresponding author. Tel.: +91 1332 285801; fax: +911332273560.

E-mail addresses: vinodfcy@iitr.ernet.in, vinodfcy@gmail.com (V.K. Gupta).

${ }^{1}$ KFUPM Chair Professor, Chemistry Department, King Fahd University of Petroleum and Minerals, Dhahran, Saudi Arabia (w.e.f. January 2010).
}

Schiff's bases (SB) have been found to act as ion carriers in the polymeric membrane. The geometric and cavity control of host-guest complexation and modulation of lipophilicity in SBs provide remarkable selectivity [5], sensitivity and stability for specific ion. Thus, SB have attracted increasing attention for determining rare earth metals such as $\mathrm{Gd}^{3+}[6], \mathrm{Tb}^{3+}[7], \mathrm{Ce}^{3+}[8,10]$, $\mathrm{Nd}^{3+}[9], \mathrm{La}^{3+}$ [11], $\mathrm{Cr}^{3+}$ [12], $\mathrm{EU}^{3+}$ [13]. The 1,3-diphenylpropane1,3-diylidenebis(azan-1-ylidene) diphenol (DPDBD) is a newly synthesized Schiff base and is known to form complex with Praseodymium. This paper presents the comparative result of sensors based on DPDBD and N,N'-bis(pyridoxylideneiminato) NBPD as a ionophore. The sensor based on DPDBD gives better performance than sensor based on NBPD.

\section{Experiment}

\subsection{Reagent and solution}

Dibenzoylmethane and 2-aminophenol were obtained from E. Merck and used as received. For membrane preparation, high molecular weight polyvinyl chloride (PVC), $o$-nitrophenyloctylether (o-NPOE), dibutylphthalate (DBP), tributylphosphate (TBP), diethylphthalate (DEP), chloronaphthalene (CN), dioctylphthalate (DOP), cetryltrimethylammonium-bromide 
(CTAB), and tetrahydrofuran (THF) were used as received from Fluka. Reagent grade praseodymium(III) chloride was purchased from Loba chemie India. HPLC-grade n-hexane and methanol were obtained from Ranbaxy India. All potentiometric measurements were performed at room temperature using Thermo Orion 4 star pH meter with PVC membrane based DPDBD electrode in conjunction with a SCE reference electrode.

\subsection{Synthesis of ionophores}

Ionophore is a key in component determining the membrane selectivity. Ideally, it forms reversible and relatively strong complex with targeted ion and does not complex with other ions. In order to keep the membrane composition constant, the ionophore must retain within the membrane; therefore, aside from the binding centre it must contain numerous lipophilic groups.

The ionophore1,3-diphenylpropane-1,3-diylidenebis(azan-1ylidene) diphenol $\left(\mathbf{M}_{1}, \mathbf{I}\right)$ was synthesized by refluxing $0.025 \mathrm{~mol}$ of dibenzoylmethane and $0.05 \mathrm{~mol}$ of 2-aminophenol in ethanol for 12 on a water bath. On cooling the reaction mixture a yellow color solution was obtained. The ionophore was extracted using nhexane $(2 \times 10 \mathrm{~mL})$ and the solution extractant was left overnight. Wine red color crystals were obtained. The compound obtained was recrystalized in n-hexane. The compound was stable at room temperature. Anal. Cac. for $\left[\mathrm{C}_{27} \mathrm{H}_{22} \mathrm{~N}_{2} \mathrm{O}_{2}\right]$ : C, 78.78, $\mathrm{H}, 5.46, \mathrm{~N}, 6.89$, O, 7.87\%. Found: C, 78.65, H, 5.50, N, 6.85, O, 7.89. Melting point: $54^{\circ} \mathrm{C}$. IR $(\mathrm{KBr}) \mathrm{cm}^{-1}$ : 3050(Phenolic $\left.\mathrm{OH}\right), 1535(\mathrm{C}=\mathrm{N}), 2900(-\mathrm{CH})$. The ${ }^{1} \mathrm{H}$ NMR $\left(\mathrm{CDCl}_{3}\right)$ exhibited signals at: $\delta(\mathrm{ppm}): 8.17-8.18(\mathrm{~m}$, $8 \mathrm{H}), 7.64-7.67$ ( $\mathrm{m}, 4 \mathrm{H}), 7.56-7.59(\mathrm{~m}, 6 \mathrm{H}), 7.57(2 \mathrm{H}, 1 \mathrm{~s}), 7.358(2 \mathrm{H}$, $1 \mathrm{~s})$.

The ionphore $\mathrm{N}, \mathrm{N}^{\prime}$-bis (pyridoxylideneiminato) ethylene $\left(\mathbf{M}_{2}\right.$, II) was derived by the condensation of pyridoxal with ethylenediamine according to method reported in literature [14]. Anal. Cac. for $\left[\mathrm{C}_{18} \mathrm{H}_{22} \mathrm{~N}_{4} \mathrm{O}_{4}\right]$ : C, 60.32, H, 6.19, N, 15.63. Found: C, 60.5, H, 6.4, $\mathrm{N}$, 15.7. IR $(\mathrm{KBr}) \mathrm{cm}^{-1}: 3100$ (Phenolic OH), $1623(\mathrm{C}=\mathrm{N}), 2900\left(-\mathrm{CH}_{3}\right)$, $1580(\mathrm{C}=\mathrm{N}$,pyridine $) .{ }^{1} \mathrm{H}$ NMR $\left(\mathrm{D}_{2} \mathrm{O}\right)$ exhibited signals at: $\delta(\mathrm{ppm})$ : 2.41 (s, $6 \mathrm{H} ; \mathrm{CH}_{3}$ ), 3.21(s, $\left.4 \mathrm{H}, \mathrm{CH}_{2}-\mathrm{OH}\right), 5.10$ (dd, $4 \mathrm{H},-\mathrm{CH}_{2} \mathrm{CH}_{2}-$ ), $6.50(\mathrm{~s}, 2 \mathrm{H}, \mathrm{CH}=\mathrm{N}), 7.50\left(\mathrm{~s}, 2 \mathrm{H}, \mathrm{CH}_{\text {aromatic }}\right)$.

\subsection{Development of electrode}

The PVC membranes were prepared by mixing various components (ionophore, anion excluder, plasticizer and PVC) in tetrahydrofuran. Varying amounts of the ionophore and anion excluder were dissolved together with an appropriate amount of PVC in $10 \mathrm{~mL}$ THF. To these, plasticizers viz. CN, DOP, DBBP, TBP or 0 -NPOE were added to get membranes of different compositions. The mixture was dissolved by a vigorous stirring with a glass rod. When the solution became homogenous and viscous it was poured in acrylic ring placed on smooth glass plate. The THF was then allowed to evaporate overnight at room temperature A light yellow colored membrane of $\sim 0.4$ thickness was obtained, which was then cut to optimum size and glued to one end of Pyrex glass tube with araldite.

\subsection{Equilibration of membranes and potential measurements}

The prepared membranes were equilibrated for three days in $0.01 \mathrm{M}$ praseodymium(III) solution. The potentials were measured by varying the concentration of $\mathrm{Pr}^{3+}$ in the test solution in the range $1.0 \times 10^{-10}$ to $1.0 \times 10^{-2} \mathrm{M}$ using a buffer solution Tris- $\mathrm{HCl}(\mathrm{pH} 4.0)$ with a digital potentiometer (model 5652 A, ECIL, India) by setting up the following cell assembly, employing saturated calomel electrodes (SCE) as a reference electrode.

\subsection{SCE | test solution || PVC membrane $\| 0.1 \mathrm{M} \mathrm{Na}_{2}{ }^{+}$ EDTA + 0.01 M PrCl 3 SCE}

The activity of $\operatorname{Pr}^{3+}$ ions was calculated using modified form of the Debye-Huckel equation [15].

\section{Result and discussion}

\subsection{Determination of binding constant}

The ionophore-complex formation constant was determined by a potentiometric method. In this method, the potential of sandwich membranes were measured, where only one side sandwich membrane contains the ionophore. If both membrane segments have the same ionic strength, it is convenient to assume that the activity coefficients for the complexed and uncomplexed ions are approximately equal. In that case, they can be omitted and the complex formation constant is related to the potential as follows [16]

$\beta_{\mathrm{IL}_{n}}=\left(L_{\mathrm{T}}-\frac{n R_{\mathrm{T}}}{Z_{\mathrm{I}}}\right)^{-n} \exp \left(\frac{E_{\mathrm{M}} Z_{\mathrm{I}} F}{R T}\right)$

where $L_{\mathrm{T}}$ is the total concentration of ionophore in the membrane segment, $R_{\mathrm{T}}$ is the concentration of lipophilic ionic site additives, $n$ is the ion-ionophore complexes stoichiometry, and $R, T$ and $F$ are the gas constant, the absolute temperature, and the Faraday constant. The ion I carries a charge of $z_{\mathrm{I}}$. This relationship allows for the convenient determination of formation constants of ion-ionophore complexes within the membrane phase on the basis of transient membrane potential measurements on two-layer sandwich membranes can be if ion pairing neglected.

The resulting formation constants for Schiff base $\mathbf{M}_{\mathbf{1}}$ and $\mathbf{M}_{\mathbf{2}}$ are summarized in Table 1 . It is clear from Table 1 that the values of binding constant are grater for praseodymium ion than other metal cations. Hence, the ionophore $\mathbf{M}_{\mathbf{1}}$ and $\mathbf{M}_{\mathbf{2}}$ exhibits significant cation-binding characteristics with praseodymium ion.

\subsection{Calibration curves}

The optimum response of the $\mathbf{M}_{\mathbf{1}}$ and $\mathbf{M}_{2}$ based sensors were evaluated and presented in Table 2 and Fig. 1 . The potential response of the sensor no. 5 based on $\mathbf{M}_{1}$ exhibited a linear working concentration range from $1.0 \times 10^{-8}$ to $1.0 \times 10^{-2} \mathrm{M}$. Furthermore, it was observed that the slope of calibration curve was $20.0 \pm 0.3 \mathrm{mV} \mathrm{decade}^{-1}$ of activity of the praseodymium ion

Table 1

Formation constants of different Schiff base-metal complexes.

\begin{tabular}{lll}
\hline Metal ion & \multicolumn{2}{l}{ Formation constant $\left(\log \beta_{\mathrm{ILn} n}\right)^{\mathrm{a}}$} \\
\cline { 2 - 3 } & Schiff base $\left(\mathbf{M}_{\mathbf{1}}\right)$ & \\
\hline $\mathrm{Pr}^{3+}$ & 6.03 & Schiff base $\left(\mathbf{M}_{\mathbf{2}}\right)$ \\
$\mathrm{Lu}^{3+}$ & 2.40 & 4.50 \\
$\mathrm{Er}^{3+}$ & 2.46 & 2.00 \\
$\mathrm{Yb}^{3+}$ & 3.12 & 2.10 \\
$\mathrm{Sm}^{3+}$ & 2.50 & 2.75 \\
$\mathrm{Eu}^{3+}$ & 2.21 & 2.15 \\
$\mathrm{Ce}^{3+}$ & 2.05 & 1.92 \\
$\mathrm{Gd}^{3+}$ & 2.18 & 1.75 \\
$\mathrm{La}^{3+}$ & 2.85 & 1.60 \\
$\mathrm{Nd}^{3+}$ & 2.96 & 2.20 \\
$\mathrm{Ho}^{3+}$ & 2.60 & 2.75 \\
$\mathrm{Tm}^{3+}$ & 2.10 & 2.30 \\
$\mathrm{Cr}^{3+}$ & 1.98 & 1.80 \\
$\mathrm{~Pb}^{2+}$ & 2.40 & 1.50 \\
$\mathrm{Zn}^{2+}$ & 4.50 & 2.15 \\
$\mathrm{~K}^{+}$ & 1.30 & 3.10 \\
$\mathrm{Na}^{+}$ & 1.50 & 1.20 \\
\hline
\end{tabular}

a $n=3, \mathrm{RSD}<1.3$. 


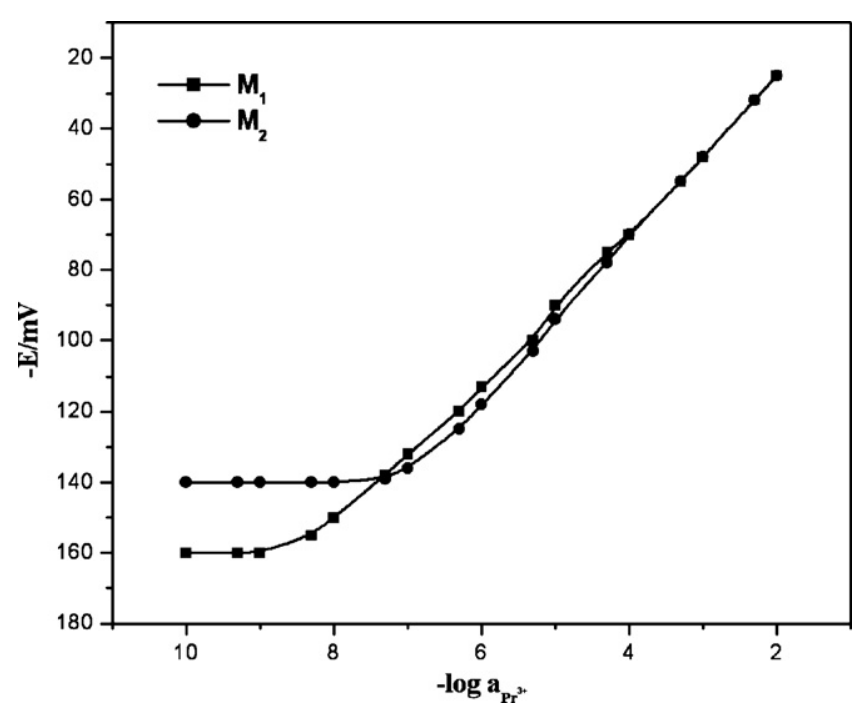

Fig. 1. Calibration plot of the praseodymium ion-electrode with ionophore $\mathbf{M}_{1}$ and $\mathbf{M}_{2}$.

concentration. The detection limit of the electrode was determined from the intersection of the extrapolated segments of the calibration graph and was estimated to be $5.0 \times 10^{-9} \mathrm{M}$. The electrode (no. 10) based on $\mathbf{M}_{2}$ exhibits a Nernstian slope of $19.3 \pm 0.1 \mathrm{mV}$ decade $^{-1}$ of activity in the concentration range $1.0 \times 10^{-7}$ to $1.0 \times 10^{-2} \mathrm{M}$ with a limit of detection $5.0 \times 10^{-8} \mathrm{M}$. Both the membrane sensors show best compatible results with o-NPOE.

\subsection{Life time of proposed sensor}

Lipophilicity of the ionophore and dielectric constant of plasticizer has been found to affect the potential response and life time [17] of the PVC membrane. The membranes were prepared using different plasticizer, among them the membrane sensor based on o-NPOE and $\mathbf{M}_{\mathbf{1}}$ (no. 5) exhibited life time of three months, and sensor based on 0 -NPOE and $\mathbf{M}_{2}$ (no.10) showed life time of one month. Thus, it is clear that the sensor no. 10 exhibits small life time as compared to sensor no.5. One of the reasons for small life time for the sensor no. 10 is that the $\mathbf{M}_{\mathbf{2}}$ is partially soluble in water therefore, $\mathbf{M}_{\mathbf{2}}$ may leach out from the membrane to solution. The life time of different membrane of different compositions calculated are listed in Table 2. The best values were obtained for 0 -NPOE based sensors probably because of their grater polarity and dielectric constant

\subsection{Effect of $\mathrm{pH}$ and non-aqueous solvent}

In order to evaluate the $\mathrm{pH}$ effect on sensor performance, the potentials were determined in the $\mathrm{pH}$ range 2.0-10 using different

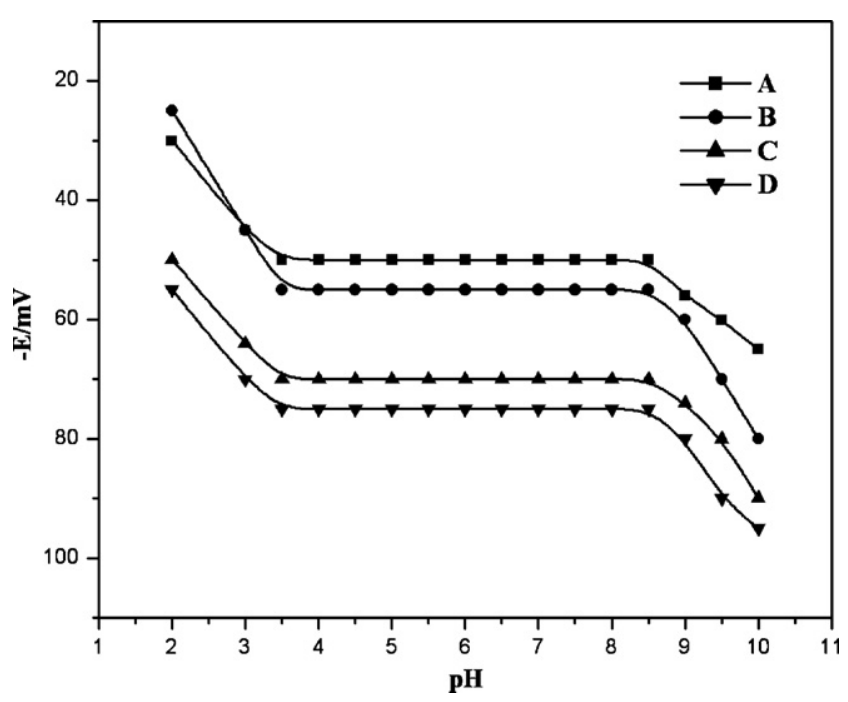

Fig. 2. Effect of pH on cell potential of sensor no. 5 (A) $1.0 \times 10^{-3} \mathrm{M}$, (C) $1.0 \times 10^{-4} \mathrm{M}$ and sensor no.10 at (B) $1.0 \times 10^{-3} \mathrm{M}$, (D) $1.0 \times 10^{-4} \mathrm{M} \mathrm{Pr}^{3+}$ solutions.

pH Tris- $\mathrm{HCl}$ buffers for $1.0 \times 10^{-3} \mathrm{M}$ and $1.0 \times 10^{-4} \mathrm{M} \mathrm{Pr}^{3+}$ solutions. The $\mathrm{pH}$ of the solution was adjusted by the addition of dilute solution of hydrochloric acid or sodium hydroxide. The respective results are depicted in Fig. 2, where the potentials remained constant from the $\mathrm{pH}$ range $3.5-8.5$ for sensors no. 5 and 10 . Beyond this range, a gradual change in potential was observed. Therefore, the $\mathrm{pH}$ range 3.5-8.5 was taken as the working $\mathrm{pH}$ range of the sensor. The potential increase at higher $\mathrm{pH}(>8.5)$ may be due to formation of some $\operatorname{Pr}^{3+}$ hydroxyl complexes in the solution. The potential decrease indicates at $\mathrm{pH}<3.5$ that the membrane sensor responds to $\mathrm{H}^{+}$ion.

The effect of partially non-aqueous medium using methanolwater; ethanol-water and acetonitrile-water mixture was also monitored on the functioning of the sensor no. 5 and the obtained results are presented in Table 3. It is observed that the values of slope and working concentration range remain constant up to $15 \%$ non-aqueous content at higher percentage of non-aqueous content the slope decreased. Therefore, the sensor can be satisfactorily used for the determination of praseodymium in mixtures up to $15 \%$ percentage of non-aqueous content.

\subsection{Response time behavior of the proposed electrode}

Response time of the sensor (no. 5) was investigated by dipping method [18-21] and was measured at various concentrations $\left(1.0 \times 10^{-2}\right.$ to $\left.1.0 \times 10^{-6} \mathrm{M}\right)$ of the test solution. The respective results are presented in Fig. 3. In all concentrations electrode reaches its equilibrium response quickly $(<8 \mathrm{~s})$. To evaluate the

Table 2

Optimization of membrane composition of praseodymium sensors.

\begin{tabular}{|c|c|c|c|c|c|c|c|c|c|}
\hline \multirow[t]{2}{*}{ Sensor no. } & \multicolumn{4}{|c|}{ Composition (w/w, mg) } & \multirow{2}{*}{$\begin{array}{l}\text { Slope (mV decade }{ }^{-1} \\
\text { of activity) }\end{array}$} & \multirow[t]{2}{*}{ Linear working range (M) } & \multirow{2}{*}{$\begin{array}{l}\text { Detection } \\
\text { limit }(M)\end{array}$} & \multirow{2}{*}{$\begin{array}{l}\text { Response } \\
\text { time }(s)\end{array}$} & \multirow{2}{*}{$\begin{array}{l}\text { Life time } \\
\text { (months) }\end{array}$} \\
\hline & Ionophore & NATBP & Plasticizer & PVC & & & & & \\
\hline 1 & $\mathbf{M}_{1}, 8$ & 5 & $300, \mathrm{CN}$ & 150 & $18.1 \pm 0.3$ & $1.0 \times 10^{-5}$ to $1.0 \times 10^{-2}$ & $5.5 \times 10^{-6}$ & 25 & 2.5 \\
\hline 2 & $\mathbf{M}_{1}, 8$ & 5 & 300, ТВР, & 150 & $19.1 \pm 0.2$ & $1.0 \times 10^{-6}$ to $1.0 \times 10^{-2}$ & $4.0 \times 10^{-7}$ & 15 & 3.0 \\
\hline 3 & $\mathbf{M}_{1}, 8$ & 5 & 300, DBBP & 150 & $18.5 \pm 0.2$ & $3.1 \times 10^{-6}$ to $1.0 \times 10^{-2}$ & $1.2 \times 10^{-6}$ & 20 & 3.0 \\
\hline 4 & $\mathbf{M}_{1}, 8$ & 5 & 300, DOP & 150 & $17.3 \pm 0.1$ & $1.0 \times 10^{-5}$ to $1.0 \times 10^{-2}$ & $1.5 \times 10^{-6}$ & 23 & 2.5 \\
\hline 5 & $\mathbf{M}_{1}, 8$ & 5 & $300,0-N O P E$ & 150 & $20.0 \pm 0.3$ & $1.0 \times 10^{-8}$ to $1.0 \times 10^{-2}$ & $5.0 \times 10^{-9}$ & $<8$ & 3.0 \\
\hline 6 & $\mathbf{M}_{2}, 8$ & 5 & $300, \mathrm{CN}$ & 150 & $17.0 \pm 0.4$ & $5.0 \times 10^{-5}$ to $1.0 \times 10^{-2}$ & $3.0 \times 10^{-5}$ & 30 & 1.7 \\
\hline 7 & $\mathbf{M}_{2}, 8$ & 5 & 300, TBP & 150 & $19.2 \pm 0.2$ & $1.0 \times 10^{-5}$ to $1.0 \times 10^{-2}$ & $5.2 \times 10^{-6}$ & 18 & 1.2 \\
\hline 8 & $\mathbf{M}_{2}, 8$ & 5 & 300, DBBP & 150 & $16.0 \pm 0.3$ & $1.6 \times 10^{-5}$ to $1.0 \times 10^{-2}$ & $4.0 \times 10^{-6}$ & 20 & 1.0 \\
\hline 9 & $\mathbf{M}_{2}, 8$ & 5 & 300, DOP & 150 & $16.7 \pm 0.2$ & $5.0 \times 10^{-5}$ to $1.0 \times 10^{-2}$ & $2.5 \times 10^{-5}$ & 23 & 1.5 \\
\hline 10 & $\mathbf{M}_{2}, 8$ & 5 & $300, o-N P O E$ & 150 & $19.8 \pm 0.3$ & $3.1 \times 10^{-6}$ to $1.0 \times 10^{-2}$ & $5.0 \times 10^{-8}$ & 12 & 1.0 \\
\hline
\end{tabular}


Table 3

Performance of the membrane sensor no. 5 in partially non-aqueous media.

\begin{tabular}{lll}
\hline $\begin{array}{l}\text { Non-aqueous } \\
\text { content }(\%, v / v)\end{array}$ & $\begin{array}{l}\text { Working concentration } \\
\text { range }(\mathrm{M})\end{array}$ & $\begin{array}{l}\text { Slope }\left(\mathrm{mV} \text { decade }^{-1}\right. \\
\text { activity })\end{array}$ \\
\hline 0 & $1.0 \times 10^{-8}-1.0 \times 10^{-2}$ & $20.0 \times 0.1$ \\
Methanol & $1.0 \times 10^{-8}-1.0 \times 10^{-2}$ & $20.0 \times 0.1$ \\
10 & $1.0 \times 10^{-8}-1.0 \times 10^{-2}$ & $20.3 \times 0.1$ \\
15 & $1.2 \times 10^{-7}-1.0 \times 10^{-2}$ & $17.5 \times 0.3$ \\
20 & & \\
Ethanol & $1.0 \times 10^{-8}-1.0 \times 10^{-2}$ & $20.0 \times 0.1$ \\
10 & $1.0 \times 10^{-8}-1.0 \times 10^{-2}$ & $20.3 \times 0.1$ \\
15 & $1.5 \times 10^{-7}-1.0 \times 10^{-2}$ & $18.0 \times 0.5$ \\
20 & & \\
Acetonitrile & $1.0 \times 10^{-8}-1.0 \times 10^{-2}$ & $20.0 \times 0.1$ \\
10 & $1.0 \times 10^{-8}-1.0 \times 10^{-2}$ & $20.3 \times 0.1$ \\
15 & $1.3 \times 10^{-7}-1.0 \times 10^{-2}$ & $17.3 \times 0.1$ \\
20 & & \\
Acetone & $1.0 \times 10^{-8}-1.0 \times 10^{-2}$ & $20.0 \times 0.1$ \\
10 & $1.0 \times 10^{-8}-1.0 \times 10^{-2}$ & $20.3 \times 0.1$ \\
15 & $1.4 \times 10^{-7}-1.0 \times 10^{-2}$ & $17.8 \times 0.2$ \\
20 & &
\end{tabular}

reversibility of the electrode, a similar procedure with opposite direction was adapted and it was found that same curve was traced back.

\subsection{Potential response of membrane}

The ionophore, membrane composition, nature of plasticizer and additive used affect the potential response of PVC membrane $[15,22-24]$ which is the function of praseodymium ion free concentration. The measured potentials were plotted against active concentration of $\operatorname{Pr}(\mathrm{III})$ and shown in Figs. 4 and 5. From these plots the working concentration range, the slope and the response time have been evaluated and are given in Table 2 along with response of each sensor. It is clear from Table 2 that the best results are obtained when the PVC membrane have ingredients with composition: Ionophore ( $\mathbf{M}_{\mathbf{1}}$ or $\left.\mathbf{M}_{\mathbf{2}}\right)$ : NaTPB: Plasticizer: PVC as $(\mathrm{w} / \mathrm{w} ; \mathrm{mg})$ of $8: 5: 300: 150$.

\subsection{Potentiometric selectivity}

The selectivity coefficients of the prepared electrodes were determined by the fixed interference method [25]. In this method,

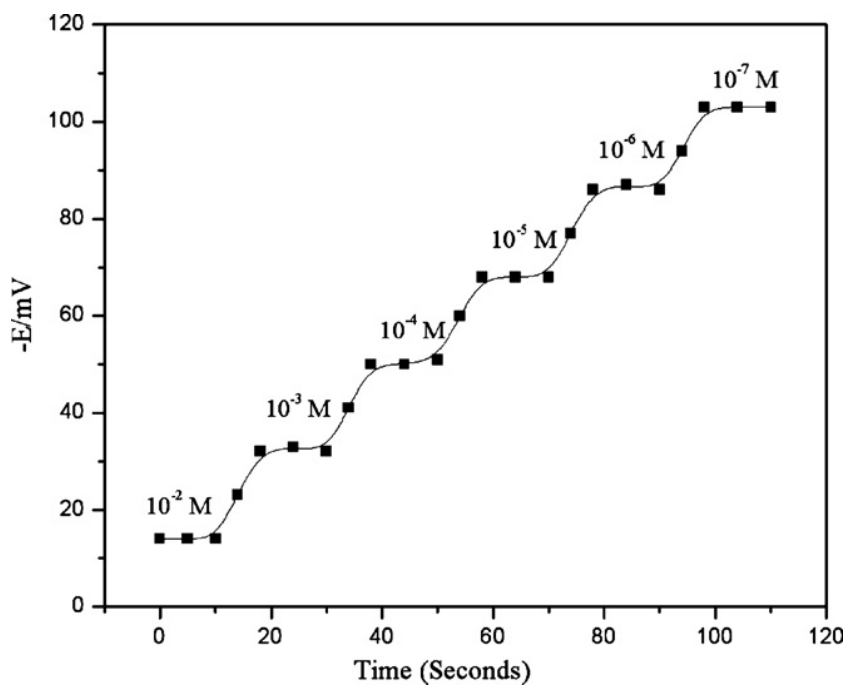

Fig. 3. Response time behavior of the membrane sensor (no. 5) based on, 1,3diphenylpropane-1,3-diylidenebis(azan-1-ylidene) diphenol ( $\left.\mathbf{M}_{1}\right)$.

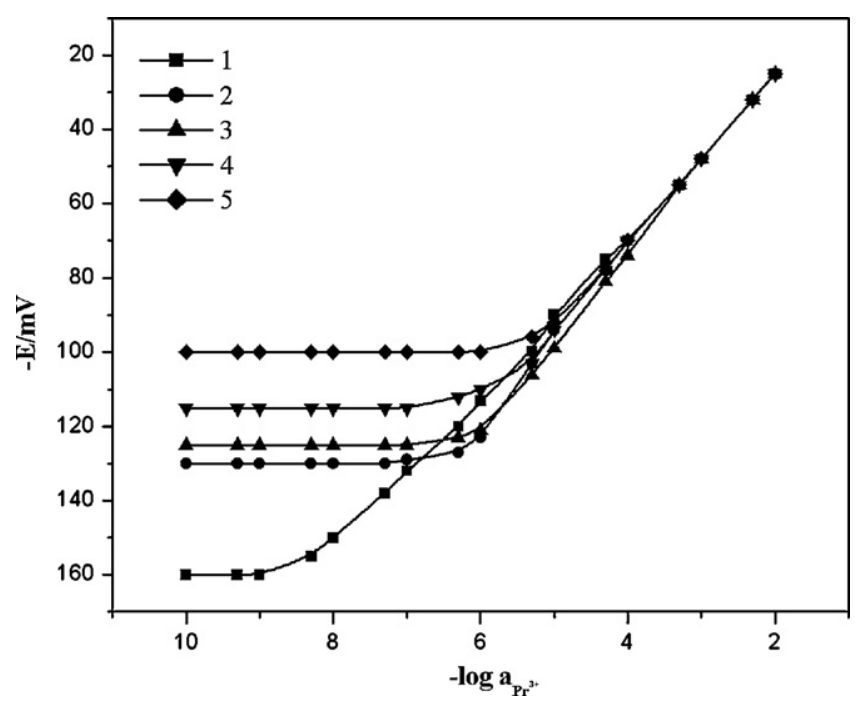

Fig. 4. Variation of membrane potential with activity of $\mathrm{Pr}^{3+}$ ions, of $\mathrm{PVC}$ based membranes of $\mathbf{M}_{1}$ with plasticizers (1) o-NPOE, (2) TBP, (3) DBBP, (4) DOP, (5) CN.

the potentials of electrode were measured at constant activity of interference ion $a_{\mathrm{B}}$ and varying the activity of primary ion, $a_{\mathrm{A}}$. The potentials obtained were plotted versus the logarithm of the activity of the primary ion. The intersection of the extrapolated linear portions of the plot indicates the value of $a_{\mathrm{A}}$ that is to be used to calculate $K_{\mathrm{Pr}^{3+}{ }_{\text {B }}^{\mathrm{Pot}}}$ from the following equation:

$K_{\mathrm{A}, \mathrm{B}}^{\mathrm{pot}}=\frac{a_{\mathrm{A}}}{\left(a_{\mathrm{B}}\right)^{\mathrm{ZA} / \mathrm{ZB}}}$

where $Z_{\mathrm{A}}$ and $Z_{\mathrm{B}}$ are the positive charges of respective ions.

The selectivity coefficients values for different interfering ions have been studied using Tris- $\mathrm{HCl}(\mathrm{pH} 4)$ buffer and result obtained for sensor no. 5 and 10 are presented in Table 4 . The selectivity coefficients data indicate that the sensor no. 5 is selective towards praseodymium ions including the transition metal ion or lanthanides metal ions. However, zinc (II) may cause some interference as selectivity coefficients for zinc (II) is slightly higher. To have an actual idea of the levels of interference caused by zinc (II) ions, some mixed run studies were performed. Fig. 6 shows that in the presence of $1.0 \times 10^{-5} \mathrm{M}$ zinc (II) ions the sensor can be used to

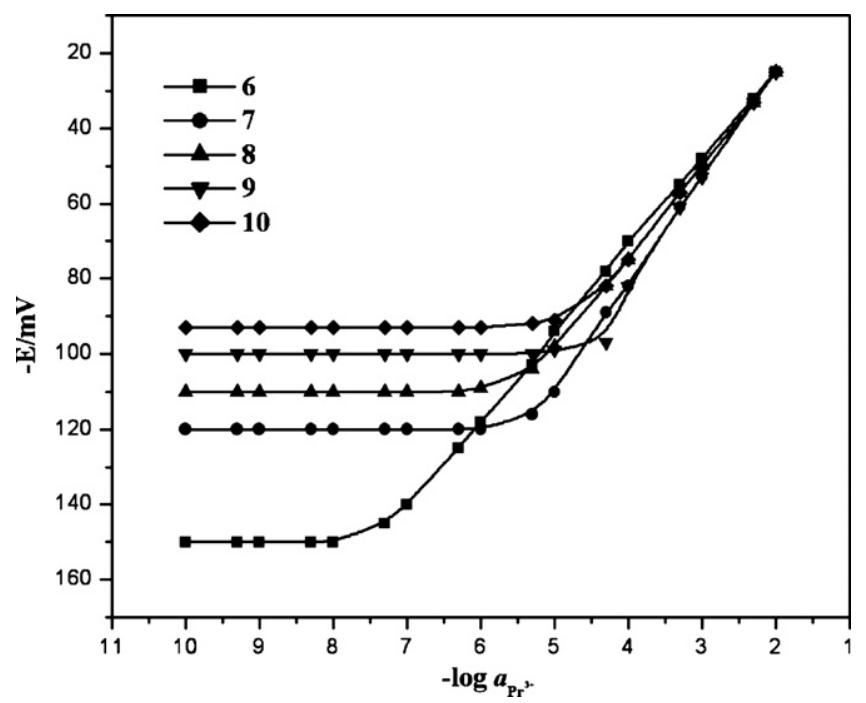

Fig. 5. Variation of membrane potential with activity of $\mathrm{Pr}^{3+}$ ions, of $\mathrm{PVC}$ based membranes of $\mathrm{M}_{2}$ with plasticizers (6) $o-\mathrm{NPOE}$, (7) TBP, (8) DBBP, (9) $\mathrm{CN}$, (12) DOP. 
Table 4

Selectivity coefficient values ( $-\log K_{\mathrm{Pr}^{3+}{ }_{\mathrm{B}}^{\mathrm{B}}}^{\mathrm{Pot}}$ ) for praseodymium(III) selective sensor by fixed interference method.

\begin{tabular}{|c|c|c|}
\hline \multirow[t]{2}{*}{ Interfering ion (B) } & \multicolumn{2}{|c|}{$\begin{array}{l}\text { Selectivity coefficients } \\
{\left[-\log K_{P_{r}^{3+},{ }_{B}}^{\text {Pot }}\right]^{\mathrm{a}} \text { by FIM method. }}\end{array}$} \\
\hline & Sensor no. 5 & Sensor no. 10 \\
\hline $\mathrm{Lu}^{3+}$ & 3.80 & 3.20 \\
\hline $\mathrm{Er}^{3+}$ & 3.38 & 2.75 \\
\hline $\mathrm{Sm}^{3+}$ & 4.05 & 3.60 \\
\hline $\mathrm{Yb}^{3+}$ & 4.85 & 4.30 \\
\hline $\mathrm{Eu}^{3+}$ & 4.02 & 3.50 \\
\hline $\mathrm{Ce}^{3+}$ & 4.18 & 3.40 \\
\hline $\mathrm{Gd}^{3+}$ & 4.20 & 3.90 \\
\hline $\mathrm{La}^{3+}$ & 3.84 & 3.15 \\
\hline $\mathrm{Nd}^{3+}$ & 4.50 & 4.10 \\
\hline $\mathrm{Ho}^{3+}$ & 4.76 & 4.25 \\
\hline $\mathrm{Tm}^{3+}$ & 3.57 & 3.12 \\
\hline $\mathrm{Cr}^{3+}$ & 2.52 & 2.10 \\
\hline $\mathrm{Al}^{3+}$ & 2.79 & 2.23 \\
\hline $\mathrm{Pb}^{2+}$ & 4.30 & 3.50 \\
\hline $\mathrm{Zn}^{2+}$ & 1.91 & 2.65 \\
\hline $\mathrm{Na}^{+}$ & 3.40 & 2.12 \\
\hline $\mathrm{K}^{+}$ & 3.85 & 3.46 \\
\hline
\end{tabular}

a $n=5, \mathrm{RSD} \%<1$.

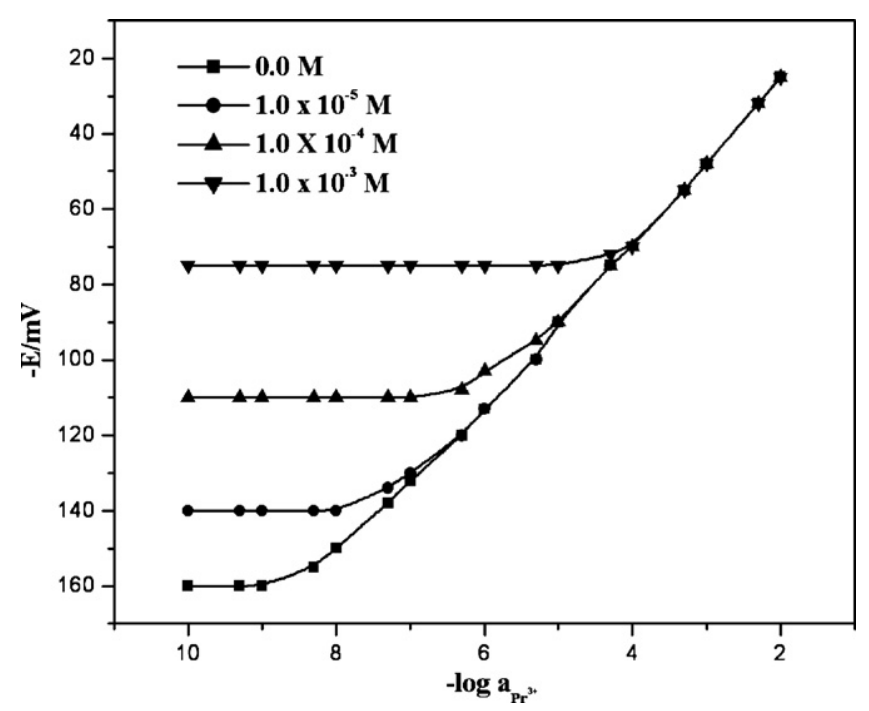

Fig. 6. Variation of membrane potential as a function of praseodymium(III) ion concentration in the presence of different concentration of zinc (II) ions.
Table 6

Comparison of the results from the proposed sensor and AAS.

\begin{tabular}{lcccc}
\hline Sample & $\begin{array}{l}\text { Added } \\
\left(\mu \mathrm{gL}^{-1}\right)\end{array}$ & $\begin{array}{l}\text { Found by proposed } \\
\text { sensor }\left(\mu \mathrm{g} \mathrm{L}^{-1}\right)\end{array}$ & $\begin{array}{l}\text { Found by } \\
\text { AAS } \\
\left(\mu \mathrm{g} \mathrm{L}^{-1}\right)\end{array}$ & $\begin{array}{l}\text { Recovery } \pm \mathrm{SD} \\
(\%)\end{array}$ \\
\hline Roorkee City & 16 & 16.05 & 16.86 & $100 \pm 0.2$ \\
& 100 & 101.05 & 99.52 & $99.9 \pm 0.1$ \\
& 500 & 502.0 & 500.32 & $500 \pm 0.1$ \\
\hline
\end{tabular}

Mean \pm SD, $n=3, \mathrm{RSD} \%<1.2$.

determine praseodymium in the concentration range $5.5 \times 10^{-8} \mathrm{M}$. The sensor no. 5 has smaller values of selectivity coefficient than sensor no. 10. Therefore, sensor no. 5 based on ligand $\mathbf{M}_{\mathbf{1}}$ exhibited better performance in presence of interfering ions as compared to sensor no. 10. Table 5 compares the selectivity coefficient values, detection limit, linear range, working $\mathrm{pH}$ range and response time of the proposed electrode with those of the best previously reported praseodymium sensors. It is clear that the selectivity coefficients of this electrode for all tested cations and detection limit are superior to those of the formerly stated praseodymium sensors.

\subsection{Analytical application}

The prepared sensor was effectively employed for the determination of praseodymium in spiked water samples. Three water samples were prepared by addition of 16,100 and $500 \mu \mathrm{g}$ praseodymium $\mathrm{L}^{-1}$ in tap water of Roorkee city and analysis was done after adjusting $\mathrm{pH}$ to 5.0. The data presented in Table 6, shows that the results obtained by the proposed sensor are comparable with Atomic Absorption spectrometer and recovery is 99.9-100.

\section{Conclusion}

A PVC based ion selective electrode was constructed by a simple procedure and applied for the determination of praseodymium at low concentrations. The use of new Schiff base $\mathbf{M}_{\mathbf{1}}$ has been investigated and incorporated in membranes having composition PVC: o-NPOE: Ionophore $\left(\mathbf{M}_{\mathbf{1}}\right)$ : NaTPB ratio $(\mathrm{w} / \mathrm{w}, \%)$ of $150: 300: 8: 5$ is found to give the best performance. The recommended sensor displayed a linear working range of $1.0 \times 10^{-8}$ to $1.0 \times 10^{-2} \mathrm{M}$, with Nernstian slope $20.0 \pm 0.3 \mathrm{mV} \mathrm{decade}^{-1}$ of activity, lower detection limit $5.0 \times 10^{-9} \mathrm{M}$. It exhibited a quick response time $<8 \mathrm{~s}$ and its potential responses were $\mathrm{pH}$ independent across the range of 3.5-8.5. It also worked satisfactorily upto $15 \%$ non-aqueous content. Moreover, it was successfully

Table 5

Comparison of the proposed praseodymium(III) selective electrode with the reported electrode.

\begin{tabular}{|c|c|c|c|c|c|c|c|}
\hline Ref. no. & Ionophore name & $\begin{array}{l}\text { Working concentration } \\
\text { range }(\mathrm{M})\end{array}$ & $\begin{array}{l}\text { Detection } \\
\operatorname{limit}(\mathrm{M})\end{array}$ & $\begin{array}{l}\text { Slope } \\
\text { ( } \mathrm{mV} \text { decade }{ }^{-1} \\
\text { of activity) }\end{array}$ & $\mathrm{pH}$ range & Selectivity coefficients ( $-\log k_{\mathrm{Pr}^{3+}{ }_{, \mathrm{B}}^{\mathrm{Pot}}}$ ) & $\begin{array}{l}\text { Response } \\
\text { time (s) }\end{array}$ \\
\hline [3] & $\begin{array}{l}\mathrm{N}^{\prime} \text {-(pyridin-2- } \\
\text { ylmethylene) } \\
\text { benzohydrazide }(\mathrm{PBH})\end{array}$ & $1.0 \times 10^{-3}$ to $1.0 \times 10^{-8}$ & $7.0 \times 10^{-9}$ & $19.8 \pm 0.3$ & $3.5-8.5$ & $\begin{array}{l}\mathrm{Yb}^{3+}(3.82), \mathrm{Sm}^{3+}(3.45), \mathrm{Lu}^{3+}(3.52) \\
\mathrm{Eu}^{+}(4.60), \mathrm{Ce}^{+}(4.0), \mathrm{Gd}^{3+}(3.52) \\
\mathrm{La}^{3+}(4.60), \mathrm{Nd}^{3+}(4.39), \mathrm{Dy}^{+}(3.45) \\
\mathrm{Ho}^{+}(4.67), \mathrm{Tm}^{+}(3.34), \mathrm{Pb}^{+}(4.34) \\
\mathrm{Mg}^{+}(4.18) \mathrm{K}+(3.82), \mathrm{Na}+(3.38) \\
\text { By MPM method. }\end{array}$ & $<10$ \\
\hline [4] & $\begin{array}{l}\text { N,N-bis( } \alpha \text {-methyl salicyli- } \\
\text { dene)diethylenetriamine }\end{array}$ & $1.0 \times 10^{-2}$ to $1.6 \times 10^{-6}$ & $6.0 \times 10^{-2}$ & $19.8 \pm 0.2$ & $3.0-8.4$ & $\begin{array}{l}\mathrm{K}^{+}(2.30), \mathrm{Sr}^{2+}(3.22), \mathrm{La}^{3+}(3.0) \\
\mathrm{Gd}^{3+}(3.45), \mathrm{Sm}^{3+}(2.88), \mathrm{Eu}^{3+}(3.01) \\
\mathrm{Nd}^{3+}(3.09), \mathrm{Dy}^{3+}(3.11), \mathrm{Cr}^{3+}(2.42) \\
\mathrm{Fe}^{3+}(2.65), \mathrm{Al}^{3+}(2.76) \\
\text { By FPM method }\end{array}$ & $<5$ \\
\hline [This work] & $\begin{array}{l}\text { 1,3-diphenyl propane-1,3- } \\
\text { diylidenebis(azan-1- } \\
\text { ylidene) } \\
\text { diphenol }\end{array}$ & $1.0 \times 10^{-2}$ to $2.0 \times 10^{-8}$ & $5.0 \times 10^{-9}$ & $20 \pm 0.1$ & $3.5-8.0$ & $\begin{array}{l}\mathrm{Yb}^{3+}(4.05), \mathrm{Sm}^{3+}(3.16), \mathrm{Lu}^{3+}(3.80), \\
\mathrm{Eu}^{++}(4.85), \mathrm{Ce}^{+}(4.18), \mathrm{Gd}^{3+}(4.20), \\
\mathrm{La}^{3+}(3.84), \mathrm{Nd}^{3+}(4.50), \mathrm{Ho}^{+}(4.76), \\
\mathrm{Tm}^{+}(3.57), \mathrm{Pb}^{+}(4.30), \mathrm{Zn}^{+}(1.91) \mathrm{K}^{+} \\
(3.85), \mathrm{Na}^{+}(3.40) . \\
\text { By FIM method. }\end{array}$ & $<8$ \\
\hline
\end{tabular}


applied to the determination of praseodymium ions in spiked water samples.

\section{Acknowledgement}

One of the authors (RAS) is thankful to Ministry of Human Resource Development (MHRD), New Delhi, India, for awarding a Senior Research Fellowship.

\section{References}

[1] J.N. Jennifer, J. Peek Jennifer, E.S. James, Eur. J. Glasses Sci. Technol. Part B 48 (2) (2007) 79-84.

[2] F. Machalett, P. Seidel, R. Muechle, Rev. Sci. Ins. 67 (1996) 1015-1017.

[3] M.R. Ganjali, P. Norouzai, F.S. Mirnaghi, S. Riahi, F. Faridbod, IEEE Sens. 7 (2007) $1138-1144$.

[4] H.A. Zamani, M.R. Ganjali, P. Norouzi, S. Meghdadi, Anal. Lett. 41 (2008) 902-916.

[5] F. Faridbod, M.R. Ganjali, R. Dinarvand, P. Norouzi, S. Riahi, Sensors 8 (2008) 1645-1703.

[6] H.A. Zamani, G. Rajabzadeh, M.R. Ganjali, P. Norouzi, Anal. Chim. Acta 598 (2007) 51-57.

[7] M.R. Ganjali, A. Ghesmi, M. Hosseini, M.R. Pourjavid, M. Rezapour, M. Shamsipur, N. Salavati, Sens. Actuat. B 105 (2005) 334-339.

[8] H.A. Zamani, M.R. Ganjali, M. Adib, Sens. Actuat. B 120 (2007) 545-550.
[9] P. Norouzi, M.R. Ganjali, A. Ahmadalinezhad, M. Adib, J. Brazil. Chem. Soc. 17 (2006) 1309-1315.

[10] V.K. Gupta, A.K. Singh, B. Gupta, Anal. Chim. Acta 575 (2) (2006) 198204.

[11] V.K. Gupta, S. Jain, S. Chandra, Anal. Chim. Acta 486 (2) (2003) 199-207.

[12] M.R. Ganjali, P. Norouzi, F. Faridbod, M. Ghorbani, M. Adib, Anal. Chim. Acta 569 (2006) 35-41.

[13] M.R. Ganjali, P. Norouzi, A. Daftari, F. Faridbod, M. Salavati-Niasari, Sens. Actuat. B 120 (2007) 673-678.

[14] I. Correia, J.C. Pessoa, M.T. Durarte, R.T. Henriques, M.F.M. Piedade, L.F. Veiros, T. Jakusch, T. Kiss, A. Dornyei, M.M.C.A. Castro, C.F.G.C. Geraldes, Chem. Eur. J. 10 (2004) 2301-2317.

[15] G.D. Christian, Analytical Chemistry, 6th ed., John Wiley \& Sons, Inc., 2003, pp 121-123.

[16] M. Yanming, E. Bakker, Anal. Chem. 71 (1999) 5279-5287.

[17] M. Telting-Diaz, E. Bakker, Anal. Chem. 73 (2001) 5582-5589.

[18] C. Macca, Anal. Chim. Acta Rev. 512 (2004) 183-190.

[19] B. Karlberg, J. Electroanal. Chem. 49 (1974) 1-5.

[20] W.E. Morf, E. Lindner, W. Simon, Anal. Chem. 47 (1975) 1596-1601.

[21] R.C. Hawkings, L.P.U. Corriveau, S.A. Kushneriuk, P.W. Wong, Anal. Chim. Acta 102 (1978) 61-83.

[22] D. Siswanta, K. Nagatska, H. Yamada, K. Kumakura, H. Hisamoto, Y. Shichi, K. Toshima, K. Suzuki, Anal. Chem. 68 (1996) 4166-4172.

[23] N. Tavakkoli, M. Shamsipur, Anal. Lett. 29 (1996) 2269-2279.

[24] M.Javanbakht, M.R. Ganjali, H. Sharghi, M. Shamsipur, Electroanalysis 11 (1999) 81-84.

[25] Y.Umezawa, P. Buhlmann, K. Umezawa, K. Tohda, S. Amemiya, Pure Appl. Chem. 72 (2000) 1851-2082. 